\title{
Study on the degree of enamel damage according to different etching protocols used for fixed orthodontic appliances
}

\author{
Studiu privind gradul de afectare a smalţului conform unor protocoale diferite de \\ demineralizare pentru aplicarea tratamentelor ortodontice fixe
}

\author{
Anamaria Florescu, Cornelia Bîcleşanu, Alexandru Burcea, \\ Ştefan Manea, Andrei Angheluță
}

Facultatea de Medicină Dentară, Universitatea „Titu Maiorescu“, Bucureşti

\begin{abstract}
REZUMAT
Aplicarea aparatelor ortodontice fixe (AOF) este la ora actuală una dintre manoperele preferate ale pacienţilor care doresc aspect estetic superior, alături de tehnicile de albire.

De cele mai multe ori, rezultatele AOF sunt spectaculoase, dar apariţia leziunilor de demineralizare şi a cariilor white spot (WS) în jurul bracketurilor reprezintă una dintre marile provocări atât pentru clinician, cât şi pentru pacient. Astfel, este important să nu se acţioneze în sensul facilitării apariţiei lor prin aplicarea unor tehnici necorespunzătoare de demineralizare a smalţului în procesul de adeziune al AOF.

Material şi metodă. Pentru acest studiu, au fost folosiţi 20 incisivi inferiori, pe care au fost colate braketuri în treimea mijlocie a feţei vestibulare. Pentru aplicarea bracketurilor au fost respectate protocolul de colaj şi indicaţiile producătorilor, doar timpul de demineralizare a smalţului a fost modificat, permiţând astfel împărţirea dinţilor în 3 grupuri: pentru primul grup, timpul de demineralizare a fost de 30 de secunde, pentru cel de-al doilea 45 de secunde şi, respectiv, 60 de secunde pentru cel de-al treilea grup.

Dinţii au fost păstraţi în apă distilată timp de o lună, după care bracketurile au fost îndepărtate, păstrând zonele de compozit restante pe dinţi. Pentru evaluarea SEM a smalţului / stratului hibrid, dinţii au fost secţionaţi longitudinal cu ajutorul unui disc diamantat, sub răcire cu apă şi la turaţie redusă.

Rezultate. Mărirea peste 30 secunde a timpului de demineralizare cu acid fosforic a smalţului, valoare care dă un tipar favorabil de demineralizare pentru adeziune, are drept consecinţă formarea unui strat hibrid cu grosime crescută în urma aplicării primerului.

Concluzii. Demineralizarea cu acid fosforic a smalţului pe o durată de 60 de secunde este urmată de formarea unui strat hibrid cu grosime mare şi de instalarea unui tipar nefavorabil de demineralizare. După îndepărtarea bracketurilor, suprafaţele de smalţ demineralizate se pot remineraliza cu ioni din salivă, dar, cu cât demineralizarea a fost mai agresivă, cu atât şi remineralizarea va fi incompletă, favorizând instalarea leziunilor white spot.
\end{abstract}

Cuvinte cheie: demineralizare, smalţ, aparat ortodontic fix, leziuni white spot

\begin{tabular}{|l} 
ABSTRACT \\
Along with whitening techniques, fixed orthodontic appliances (FOA) is currently one of the patients' favorite maneu- \\
vers looking for aesthetic appearance. Most of the time, FOA results are spectacular, but the appearance of dem- \\
ineralization and white spot lesions (WSL) around brackets is one of the great challenges for both the clinician and \\
the patient. \\
So it is important not to act to ease their appearance, by applying inappropriate enamel demin-eralization techniques \\
to the FOA adhesion process. \\
Material and method. For this study, 20 lower incisors were used and braces were bonded in the middle third of the \\
vestibular aspect. For the application of the brackets, the bonding protocol and the manufacturers' indications have \\
been respected. Only the enamel etching time was modified to allow the teeth to be divided into 3 groups: the first \\
group, the etching time was 30 seconds, for the second 45 seconds and 60 seconds respectively for the third group. \\
The teeth were kept in distilled water for one month and then the brackets were removed. The remaining composite \\
areas on the teeth were kept. For SEM evaluation of the enamel / hybrid layer, the teeth were longitudinally sectioned \\
using a diamond disk under water cooling and at low speed. \\
Results. Increasing the etching time with phosphoric acid of the enamel over 30 sec, value that gives a favorable \\
etching pattern for adhesion, has the consequence of forming a thicker hybrid layer after application of the primer.
\end{tabular}


Conclusions. Etching of the enamel for 60 seconds with phosphoric acid is followed by the formation of a thick hybrid layer and the settlement of an unfavorable etching pattern. After brackets removing, the etched enamel surfaces can be remineralized with saliva ions, but the more aggressive the etching, the more incomplete the remineralization, favoring the installation of white spot lesions.

Keywords: etching, enamel, fixed orthodontic appliances, white spot lesion

Aplicarea aparatelor ortodontice fixe (AOF) este, la ora actuală, una dintre manoperele preferate ale pacienţilor care doresc aspect estetic superior, alături de tehnicile de albire.

Rezultatele AOF sunt spectaculoase de multe ori dar nu întotdeauna ele sunt şi benefice. Astfel, apariţia leziunilor de demineralizare şi a cariilor white spot (WS) reprezintă una dintre marile provocări pentru clinician, dar şi pentru pacient. Acesta trebuie informat de la început asupra riscurilor pe care trebuie să şi le asume. In plus, dacă igiena pacientului nu este realizată corespunzător, riscul de apariţie a acestor modificări inestetice ale smalţului creşte exponenţial. Realizarea igienei dentare este oricum dificilă din cauza prezenţei bracketurilor, ligaturilor, arcurilor care împiedică periajul corect, dar şi realizarea autocurăţării prin limitarea mişcărilor musculare sau limitarea rolului salivei de a spăla suprafeţele dentare.

Deci, apariţia zonelor de demineralizare în jurul bracketurilor este un fapt cunoscut, important este să nu acţioneze şi clinicianul în sensul facilitării apariţiei lor prin aplicarea unor tehnici necorespunzătoare de demineralizare a smalţului în procesul de adeziune al AOF.

Pentru că părerile clinicienilor sunt împărţite referitor la timpul de demineralizare acidă, precum şi la zona topografică de aplicare a acidului, am efectuat acest studiu pentru a vedea efectele pe care le au asupra smalţului aceşti parametri.

Adeziunea la smalţ este o procedură clinică bazată pe tehnica de demineralizare şi o consecinţă a retenţiei micromecanice create la suprafaţa smalţului prin folosirea unui acid demineralizant şi a penetrării ulterioare a unui amestec de monomeri polimerizabili în spaţiile interprismatice pentru a forma dopurile de răşină din smalţ.

Stratul care se formează la limita smalţ-răşină compozită este alcătuit din răşina încapsulată în şi între cristale şi infiltrarea răşinii în spaţiul interprismatic, acest fapt fiind numit hibridizarea smalţului.

\section{MATERIAL ŞI METODĂ}

Pentru acest studiu au fost folosiţi 20 incisivi inferiori extraşi din motive parodontale, pe care au fost colate braketuri în treimea mijlocie a feței vestibulare. Dintii au fost spălaţi şi curăţaţi de resturi, suprafeţele au fost curăţate cu pastă profilactică (Clean Polish, Kerr). Până la efectuarea studiului, dinţii au fost păstraţi în ser fiziologic.

Materialele folosite în studiu sunt:

- acid fosforic 37\% sub formă de gel (Actino Gel, Prevest DenPro);

- primer (Opal Seal, Ultradent Products)

- bonding ortodontic fotopolimerizabil (Opal ${ }^{\circledR}$ Bond MV, Ultradent Products)

- bracketuri metalice Avex MBT.022” (fig. 1)

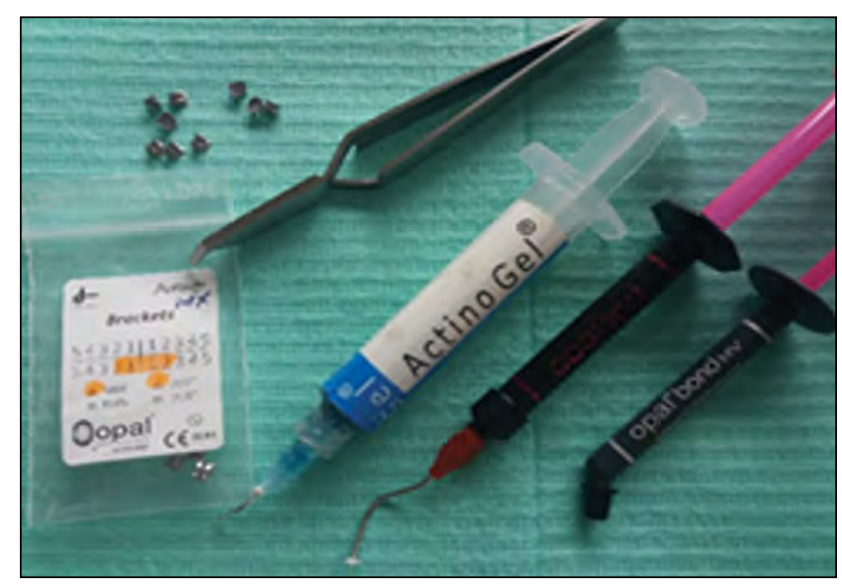

FIGURA 1. Bracketuri metalice Avex MBT.022"

\section{Protocol de colaj}

Pentru aplicarea bracketurilor au fost respectate indicaţiile producătorilor şi următorul protocol de colaj:

- demineralizarea suprafeţei smalţului cu acid fosforic 37\% (Actino Gel, PrevestDenPro), urmată de spălarea şi uscarea acesteia;

- aplicarea primerului în strat subţire pe suprafaţa demineralizată a smalţului (Opal Seal, Opal Orthodontics);

- aplicarea compozitului (Opal Bond MV, Opal Orthodontics) pe talpa bracketului în strat sub- 
ţire şi poziţionarea acestuia la nivelul dintelui; îndepărtarea excesului de material şi fotopolimerizarea răşinii adezive cu lampa cu halogen, $15 \mathrm{sec}$. dinspre mezial şi $15 \mathrm{sec}$. dinspre distal.

- bracketurile au fost poziţionate paralel cu marginea incizală, în treimea mijlocie a feţei vestibulare, la distanţă egală de suprafeţele mezială şi distală şi la mijlocul distanţei ocluzo-gingivale.

În funcţie de timpul de demineralizare, dinţii au fost împărţiţi în 3 grupe. Pentru primul grup, timpul de demineralizare a fost de $30 \mathrm{sec}$., pentru cel de-al doilea $45 \mathrm{sec}$. şi, respectiv, $60 \mathrm{sec}$. pentru al treilea grup.

Dinţii au fost păstraţi în apă distilată timp de o lună, după care bracketurile au fost îndepărtate.

Zonele de compozit restante pe dinţi nu au fost îndepărtate. Dinţii se păstrează în apă distilată până la examinarea SEM a suprafeţelor vestibulare. Pentru evaluarea microscopică a smalţului, dinţii au fost secţionaţi longitudinal cu ajutorul unui disc diamantat, sub răcire cu apă şi la turaţie redusă.

\section{Grupul 1 - Timp de demineralizare 30 sec.}

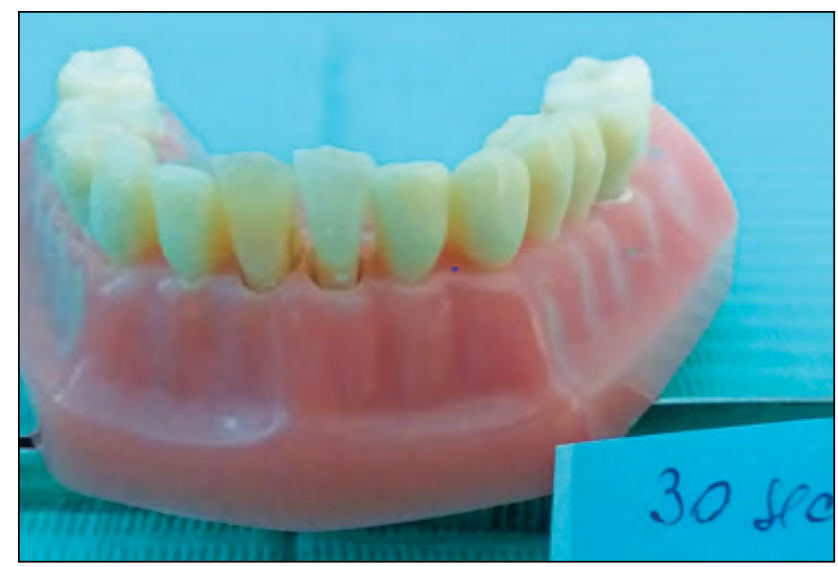

FIGURA 2. Aspectul inițial vestibular I

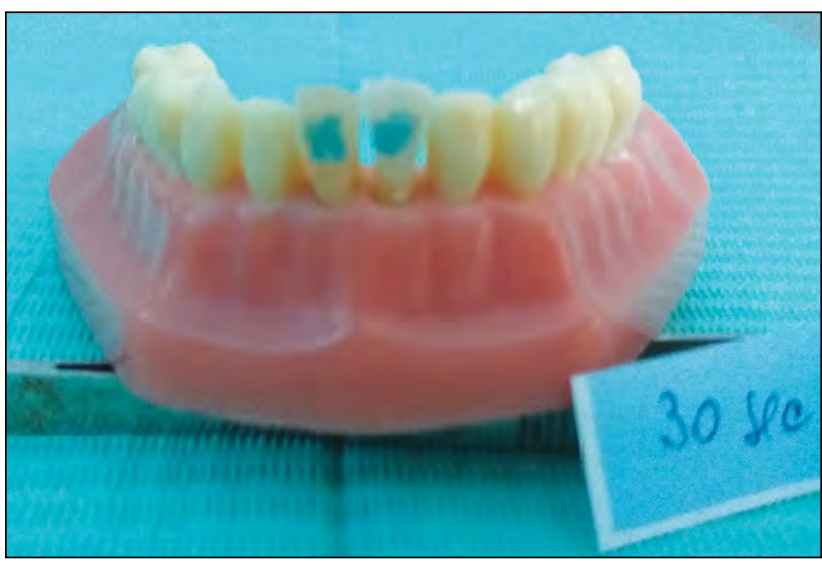

FIGURA 3. Aplicare demineralizant pe supraf. $V$

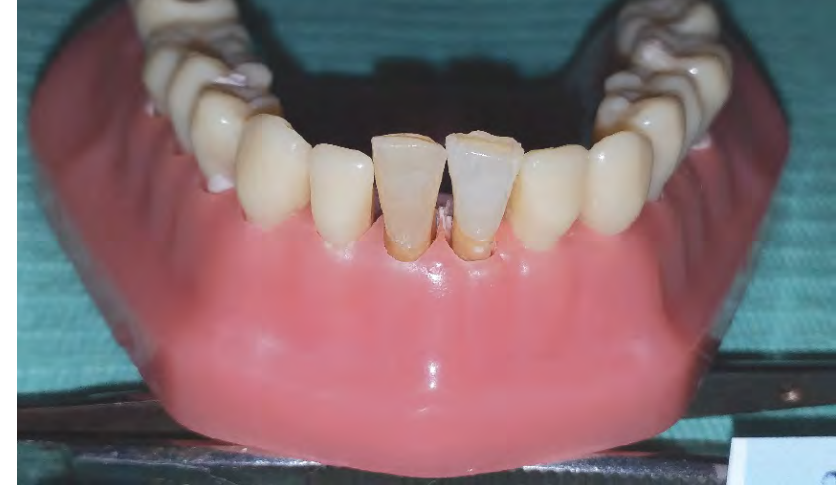

FIGURA 4. Aspect smalț demineralizat $30 \mathrm{sec}$.

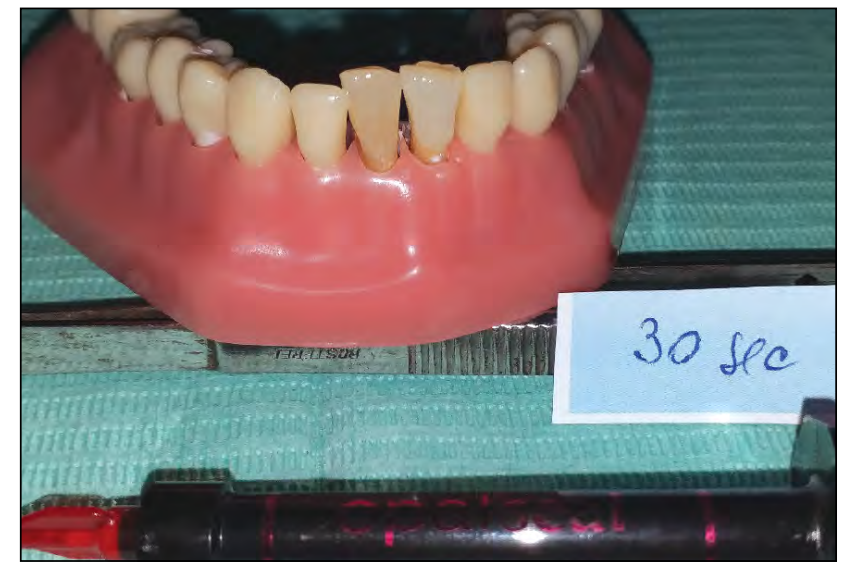

FIGURA 5. Aplicarea primerului Opal Seal
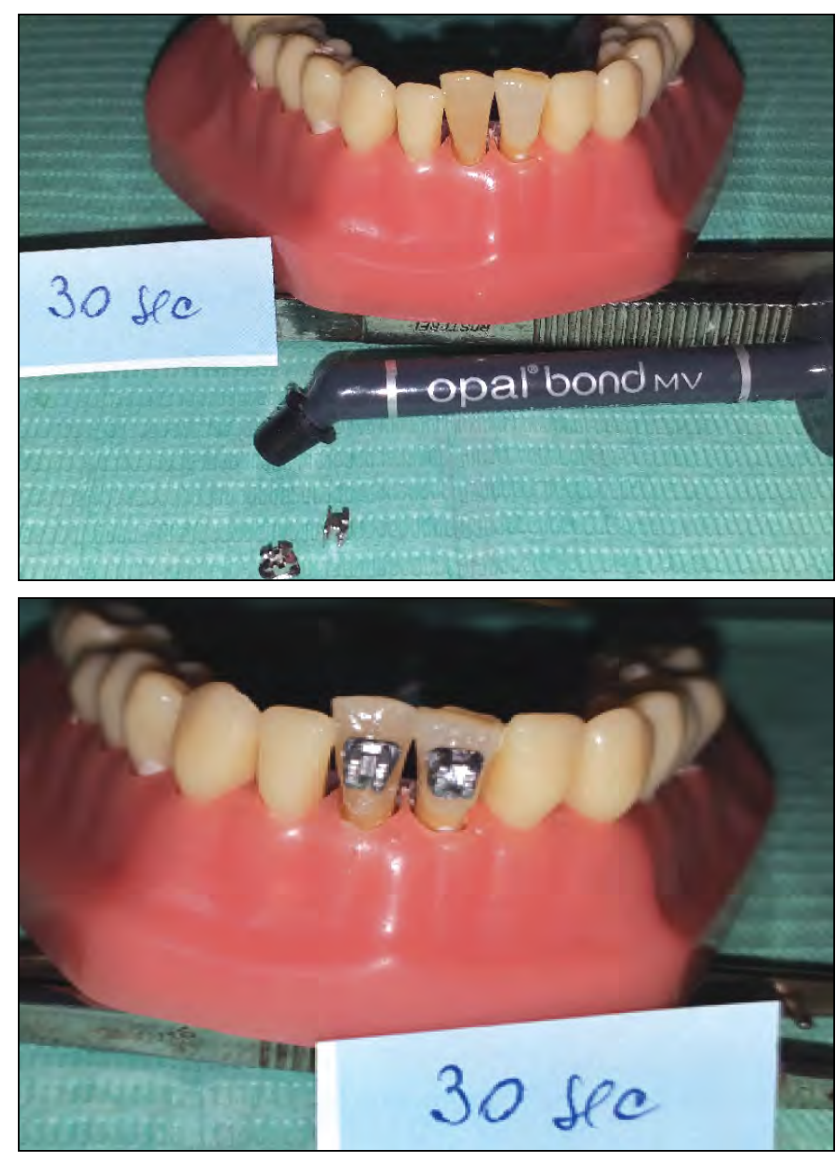

FIGURA 6. Colarea bracketurilor cu Opal Bond M 


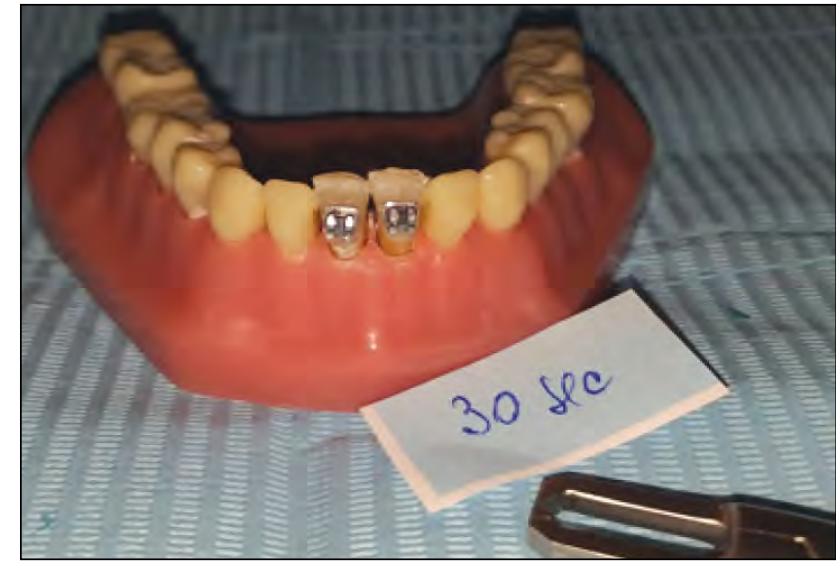

FIGURA 7. Aspect la o lună de la aplicarea bracketurilor

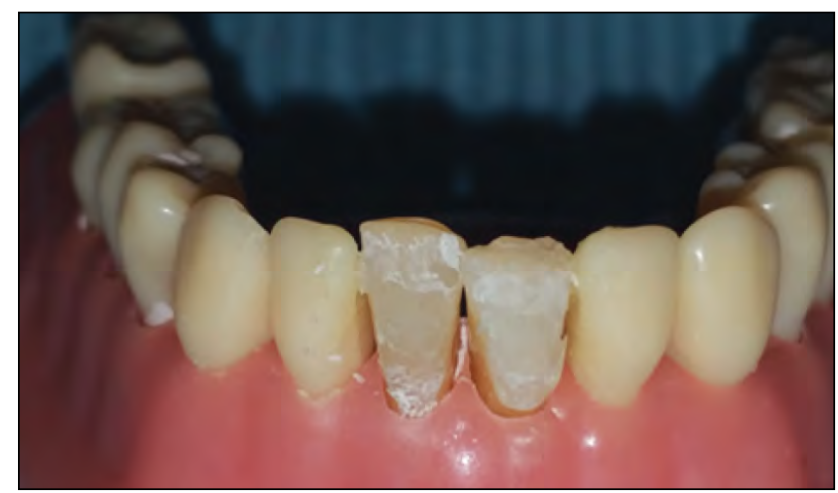

FIGURA 8. Aspectul după îndepărtarea bracketurilor

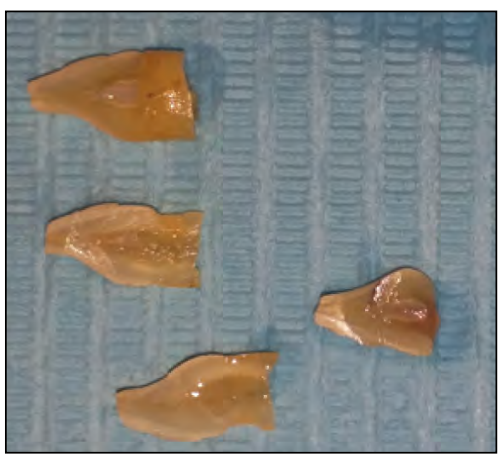

FIGURA 9. Dinții sunt secționați longitudinal

Grupul 2 - Timp de demineralizare 45 sec.

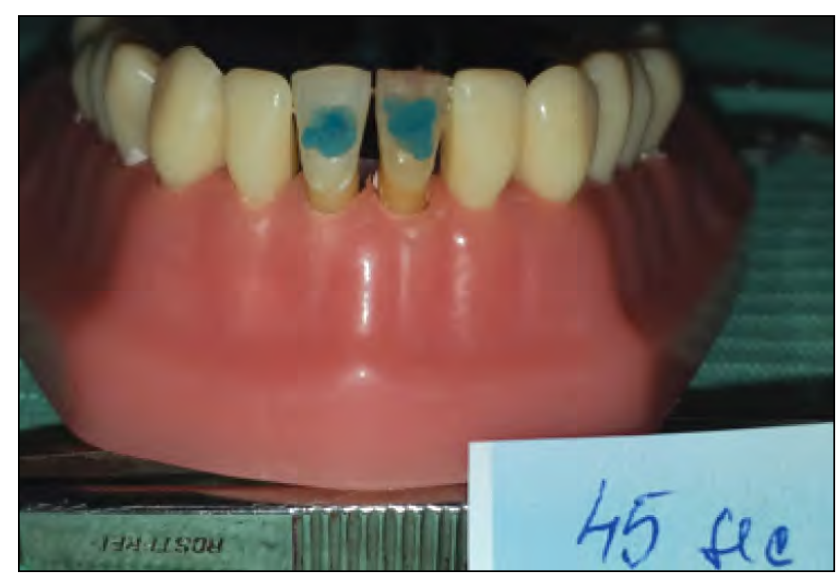

FIGURA 10. Aplicarea demineralizantului

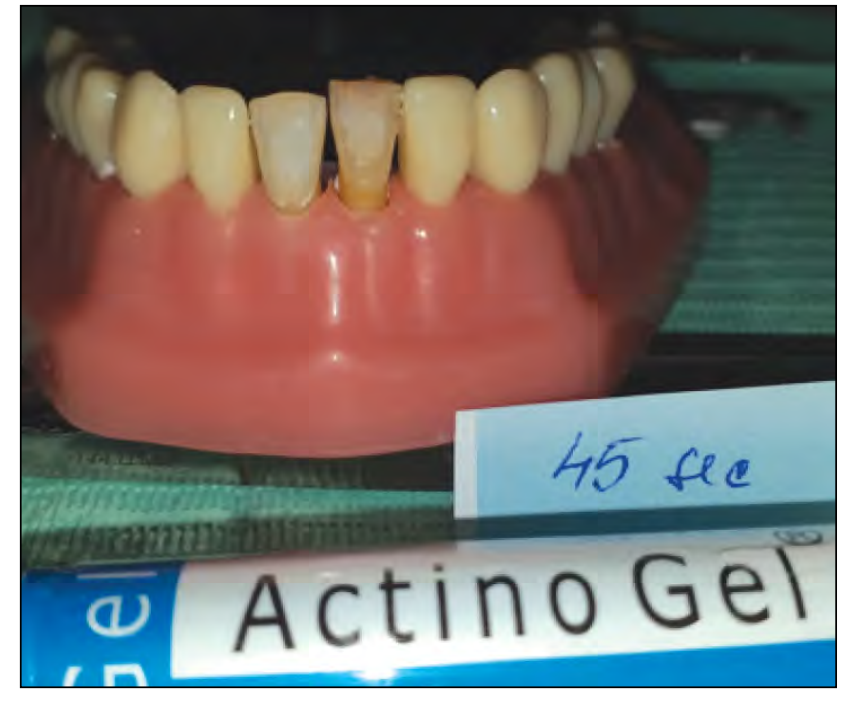

FIGURA 11. Aspectul clinic al smalțului demineralizat 45 sec.

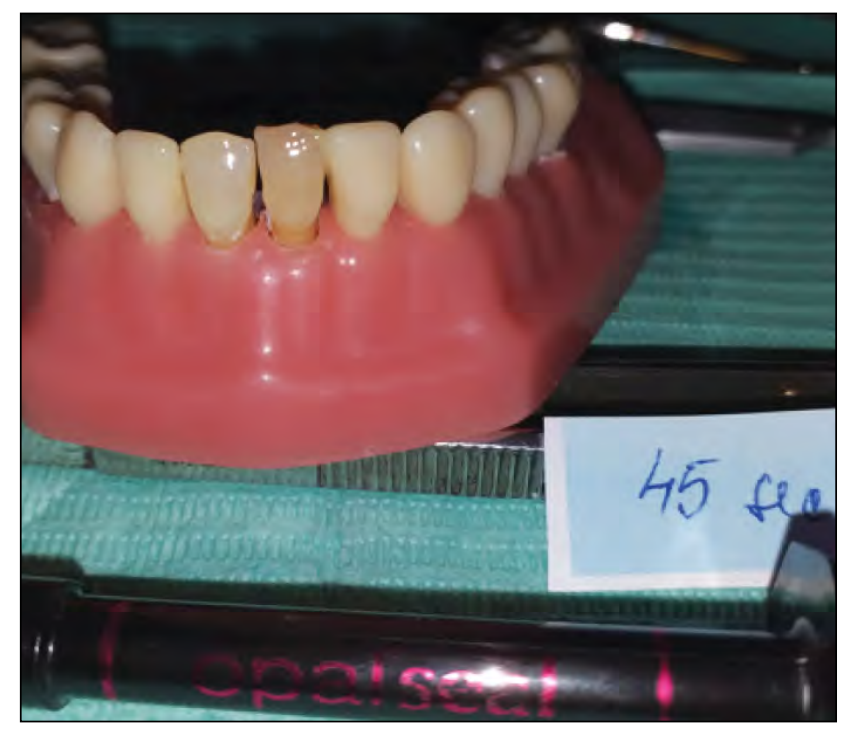

FIGURA 12. Aplicarea primerului Opal Seal

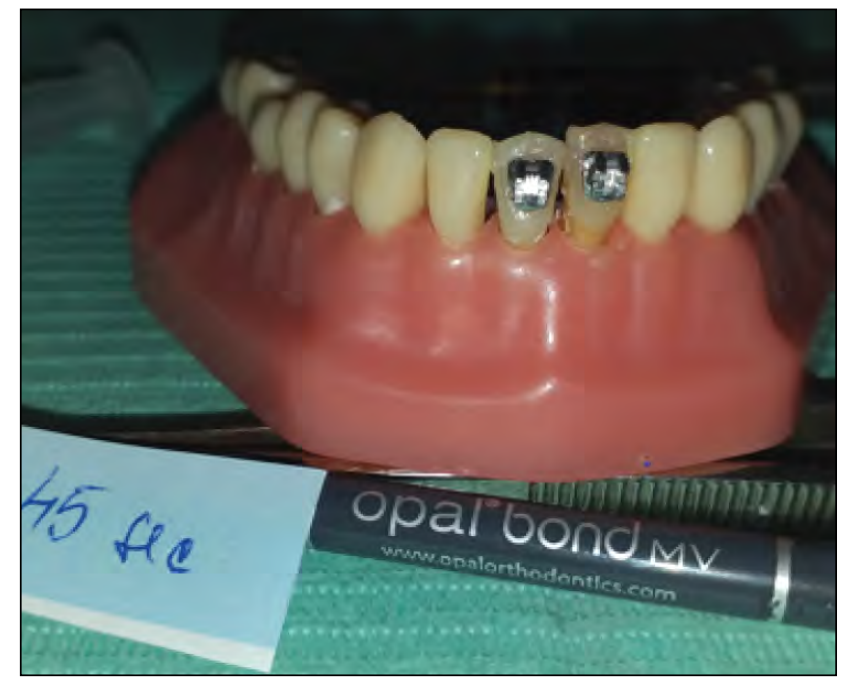

FIGURA 13. Colarea bracketurilor cu Opal Bond MV 


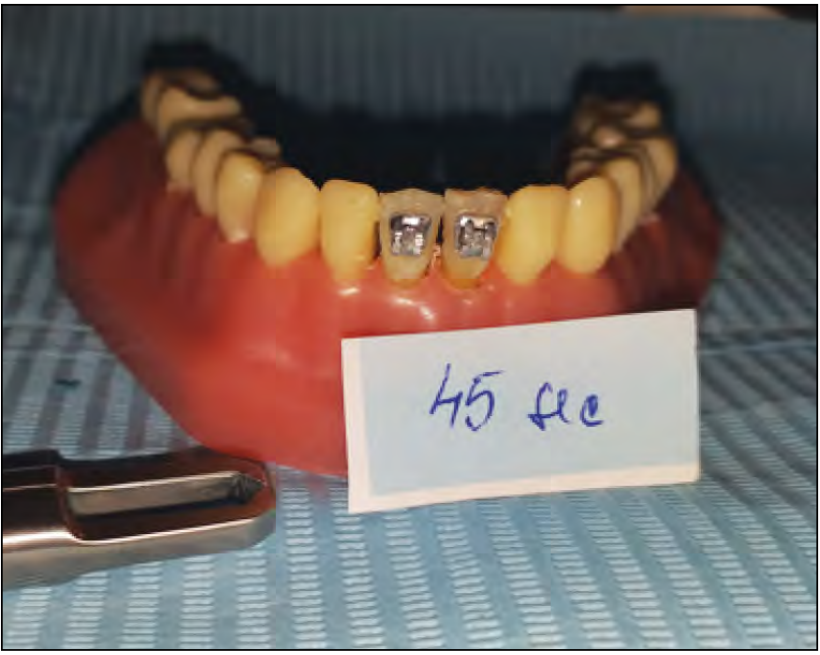

FIGURA 14. Aspectul dinților la o lună de la aplicarea bracketurilor

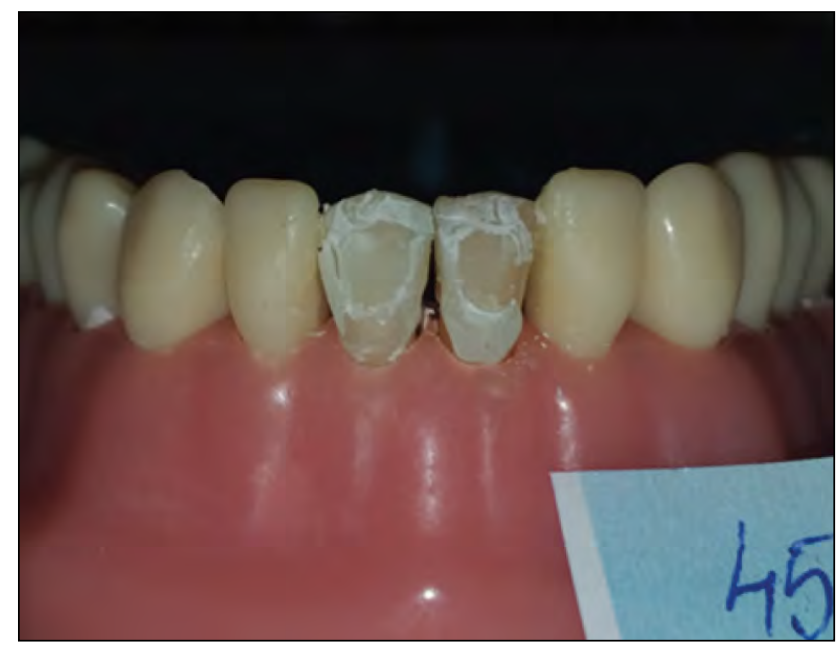

FIGURA 15. Aspect smalț după îndepartarea bracketurilor

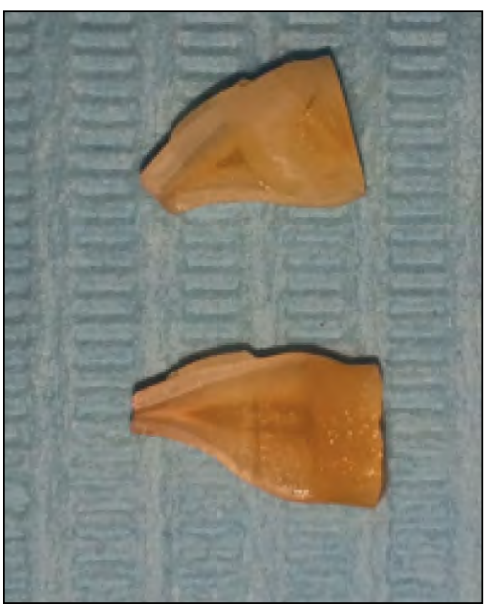

FIGURA 16. Dinții secționați longitudinal

\section{Grupul 3 - Timp de demineralizare 60 sec.}

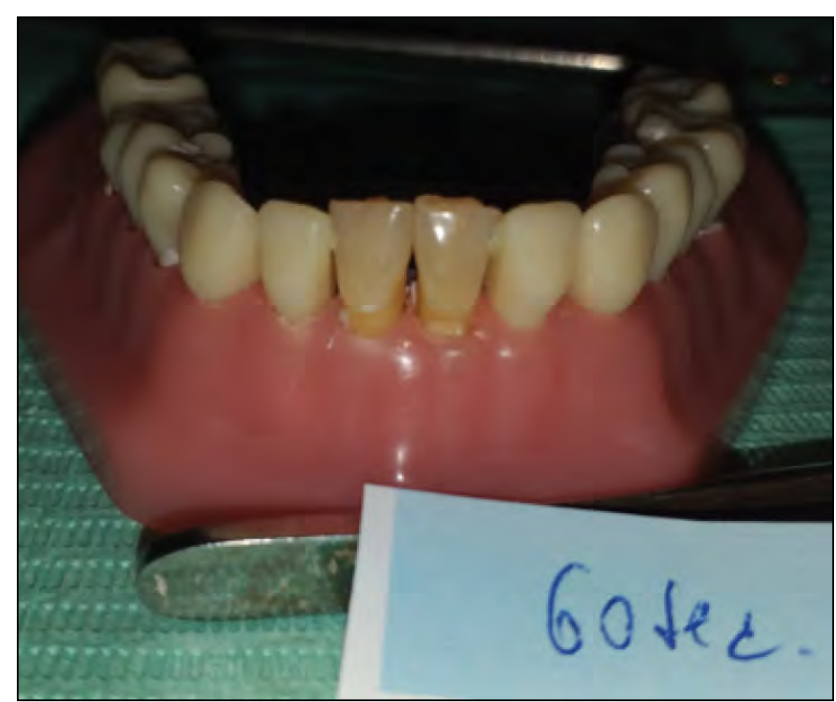

FIGURA 17. Aspectul inițial al incisivilor

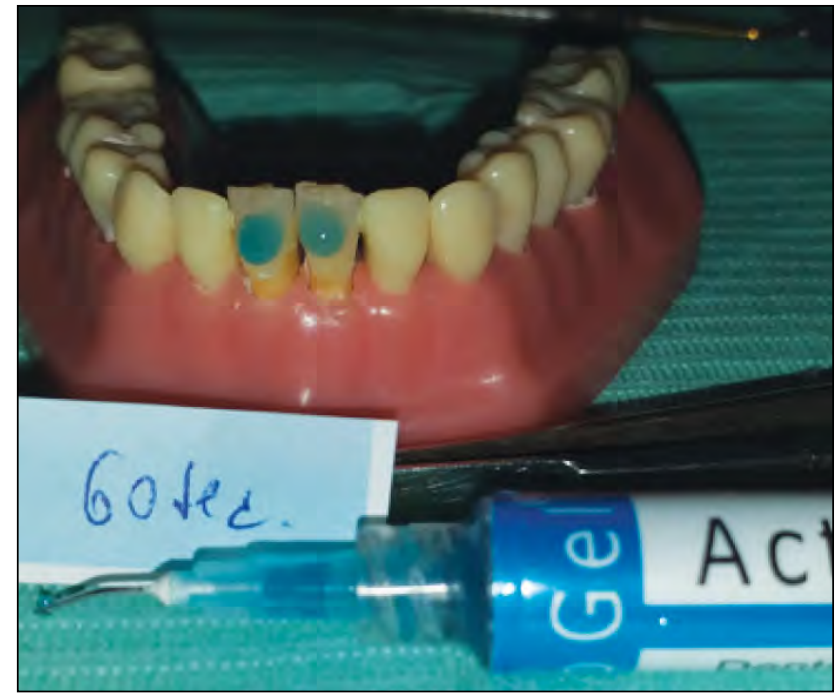

FIGURA 18. Aplicare demineralizant în treimea medie a suprafeței vestibulare

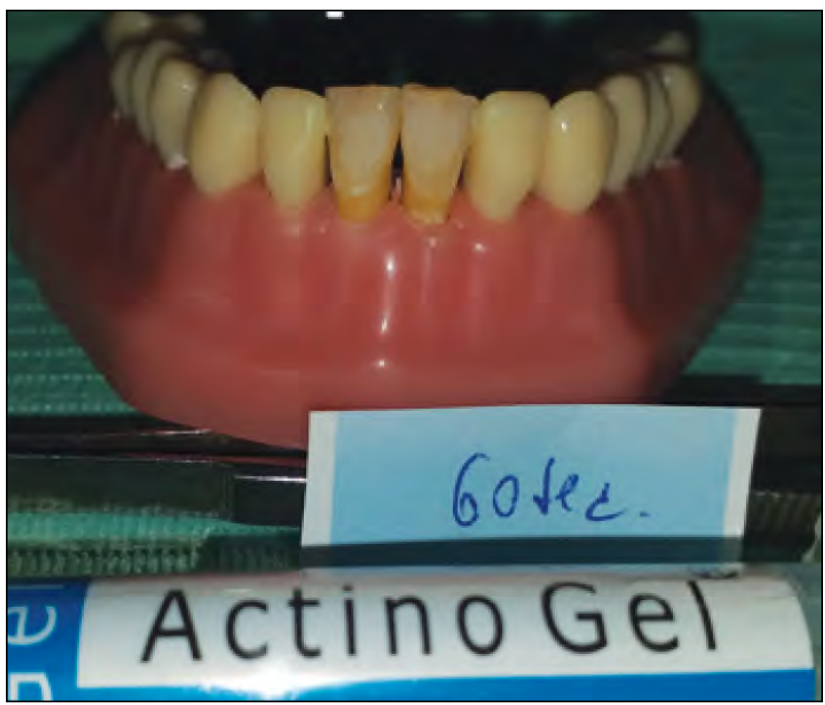

FIGURA 19. Aspectul smalțului demineralizat $60 \mathrm{sec}$. 


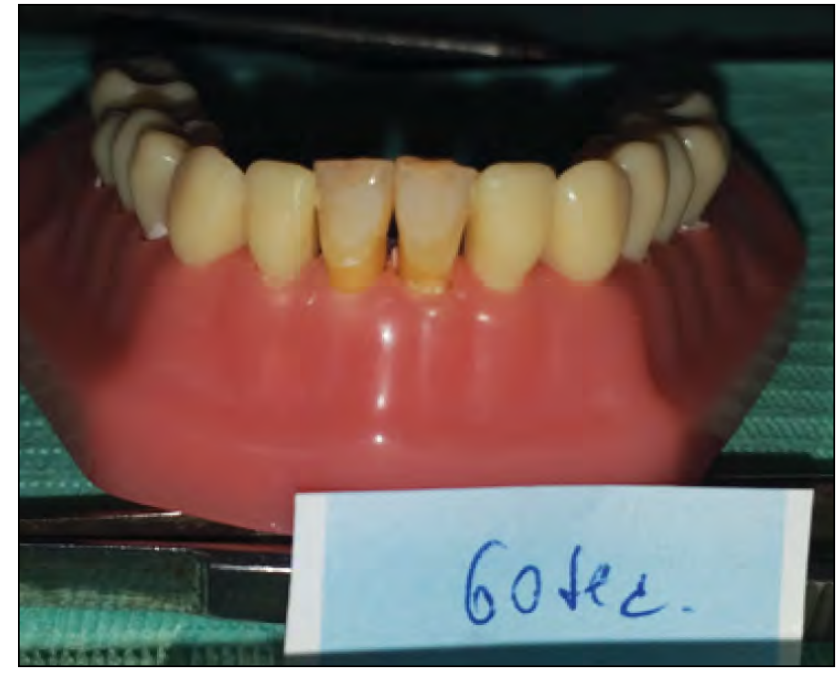

FIGURA 19. Aspectul smalțului demineralizat $60 \mathrm{sec}$. (continuare)

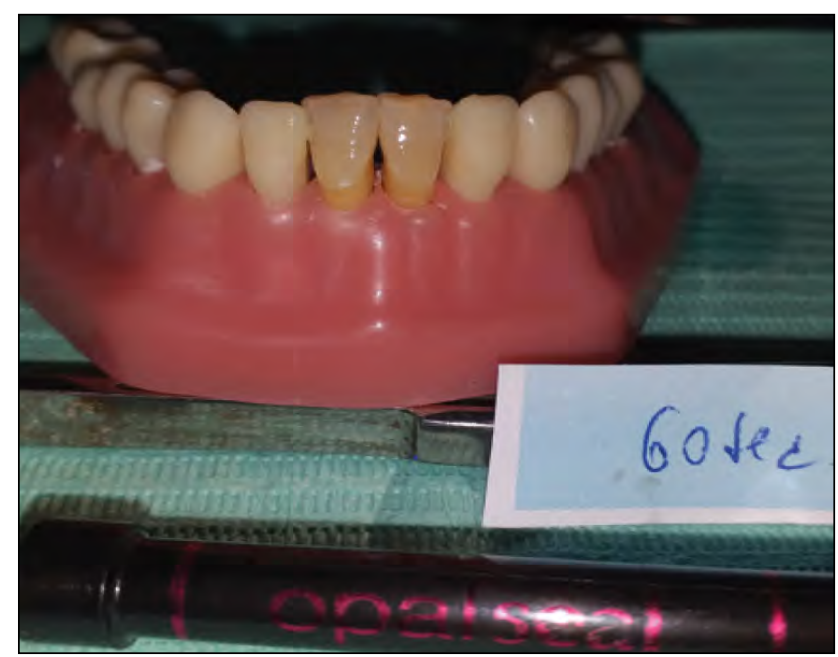

FIGURA 20. Aplicarea primerului Opal Seal

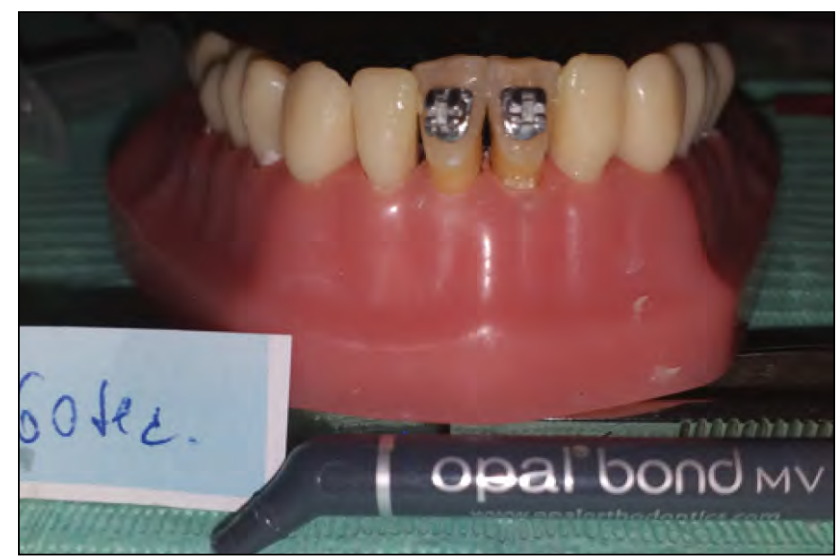

FIGURA 21. Colarea bracketurilor cu Opal Bond MV

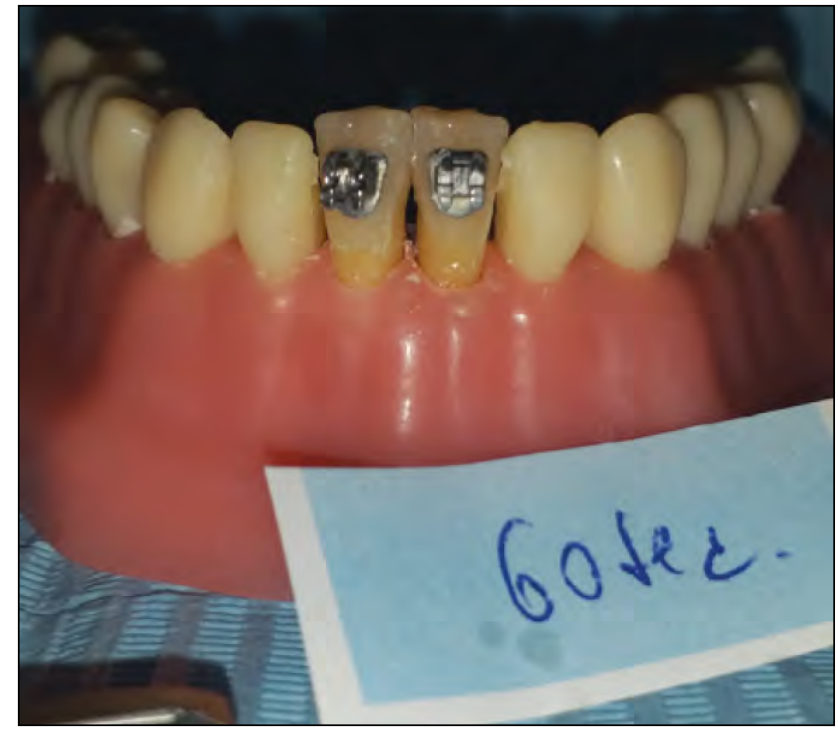

FIGURA 22. Aspect la o lună de la aplicarea bracketurilor

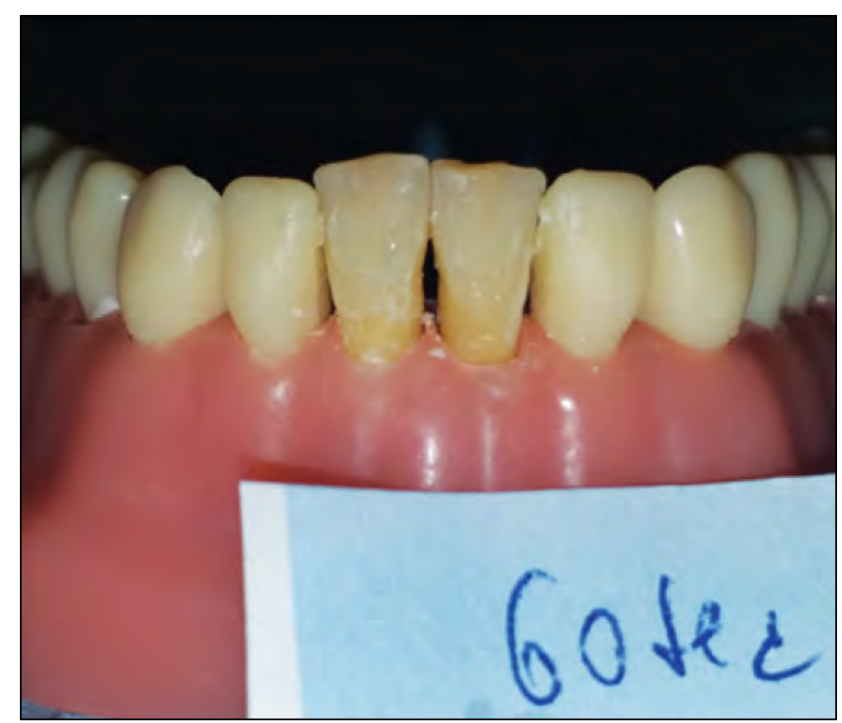

FIGURA 23. Aspectul după îndepărtarea bracketurilor

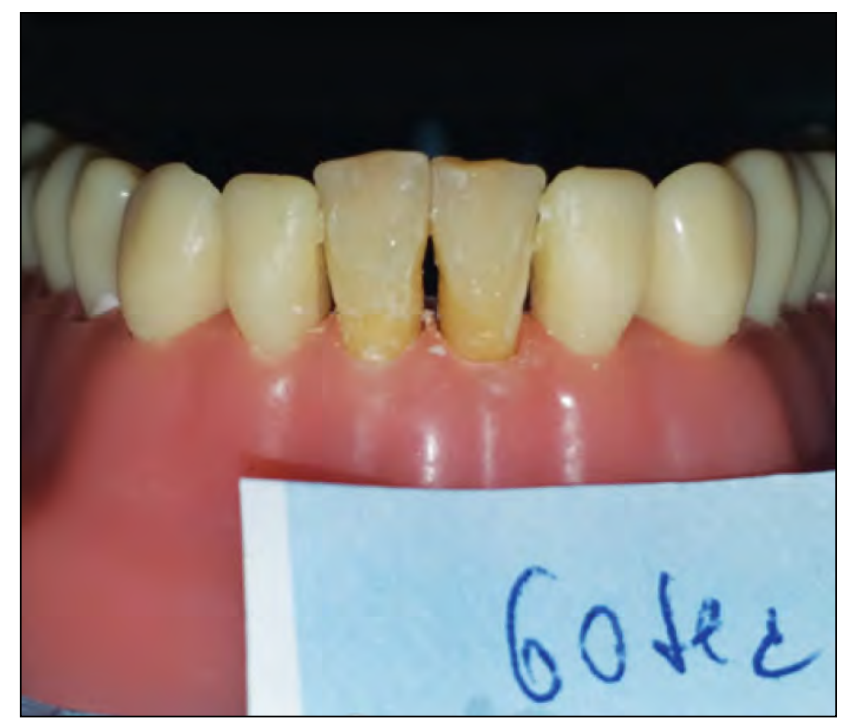

FIGURA 24. Dinții secționați longitudinal 


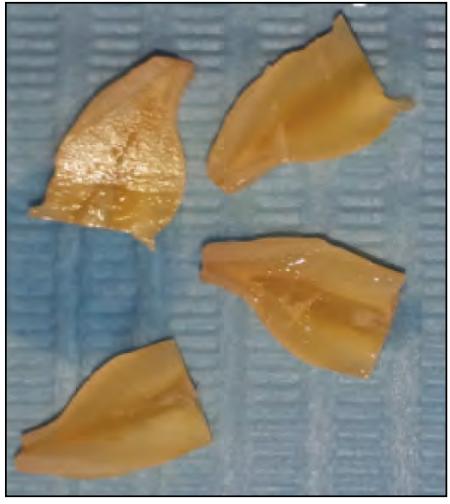

FIGURA 25. Pregătirea dinților pentru analiza SEM

\section{REZULTATE ŞI DISCUȚII}

Pe probele supuse analizei SEM a fost măsurată grosimea stratului hibrid în zone diferite al interfeţei primer-smalţ, valorile minime şi maxime fiind notate în Tabelul 1.

\section{Aspect SEM Grup 1}

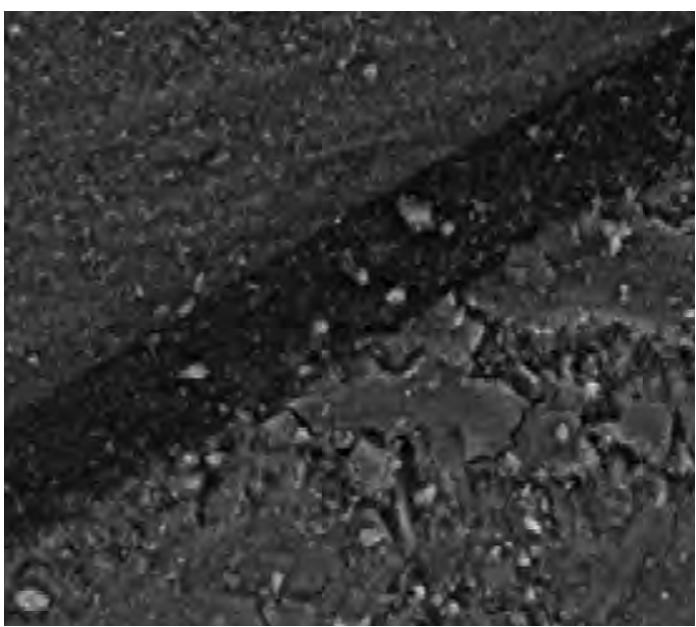

FIGURA 26. Zona smalț-primer-compozit la mărire $1.000 x$

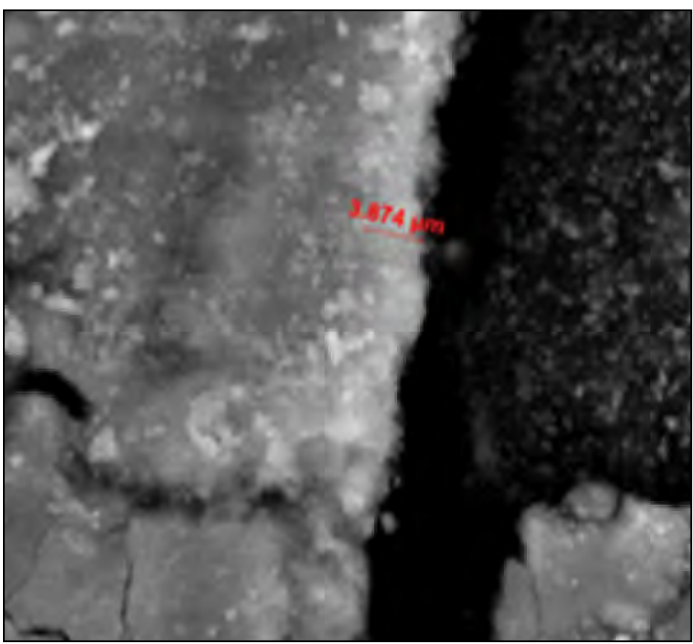

FIGURA 27. Zona smalt-smalt hibridizat-primer la mag. 5.000 x; grosimea stratului de smalț hibridizat 3,074 $\mu \mathrm{m}$

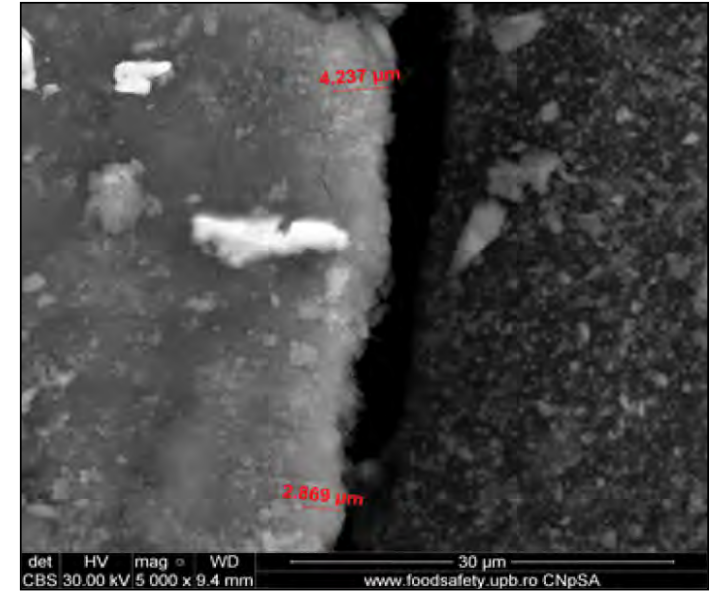

FIGURA 28. Aceeaşi zonă la mag. 5.000 x, grosimea smalțului hibridizat 2,869-4,237 $\mu \mathrm{m}$

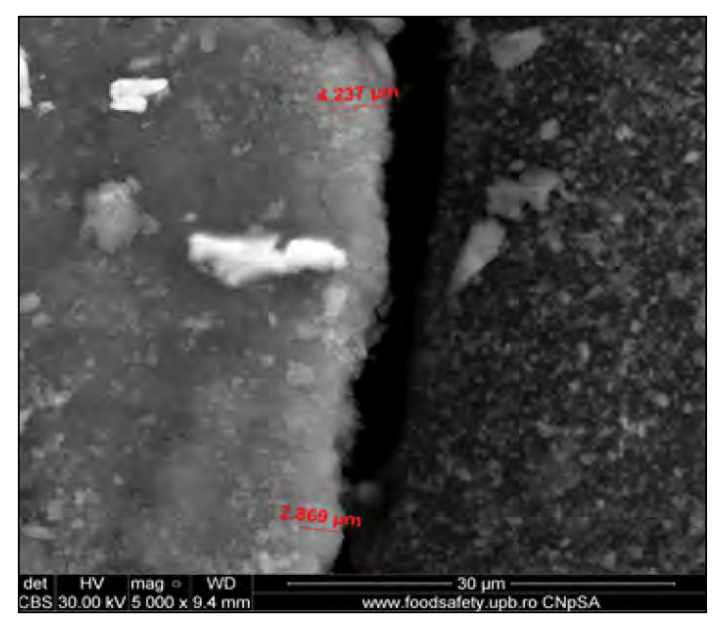

FIGURA 29. Zona de smalț- smalț hibridizat-primercompozit la mag. $5.000 x$, grosimea smaltului hibridizat 3,342-3,593 $\mu \mathrm{m}$

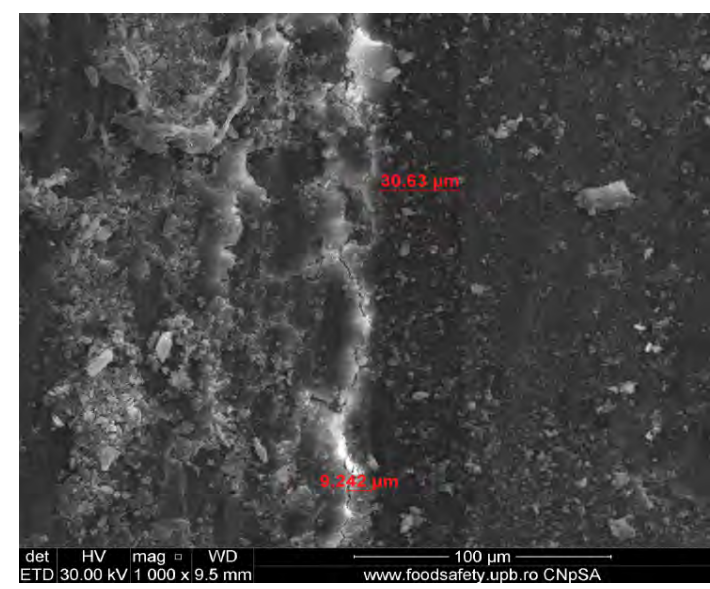

FIGURA 30. Zona de smalt- smalt hibridizat-primercompozit la mag. $1.000 \mathrm{x}$, grosimea smalțului hibridizat 9,242 $\mu \mathrm{m}$ 


\section{Aspect SEM Grup 2}

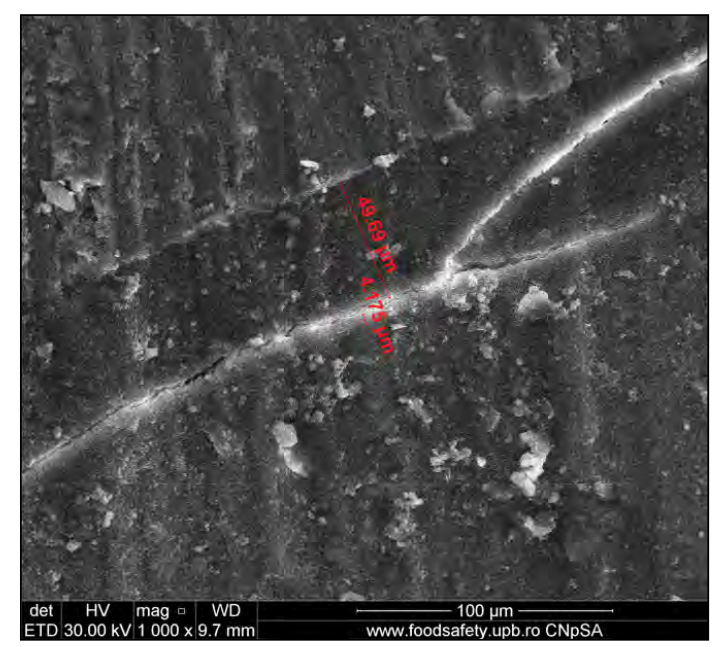

FIGURA 31. Zona de smalt-smalt hibridizat-primercompozit la mag. 1.000 x, grosimea smalțului hibridizat 4,175 $\mu \mathrm{m}$ față de grosimea primerului 49,63 $\mu \mathrm{m}$

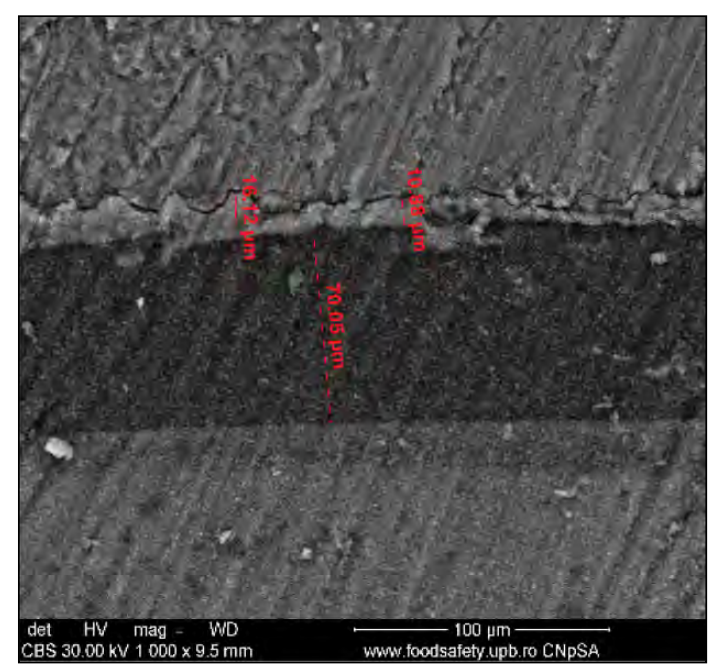

FIGURA 32. Zona de smalț-smalț hibridizat-primercompozit la mag. $1.000 x$, grosimea smalțului hibridizat $10,59-16,12 \mu \mathrm{m}$

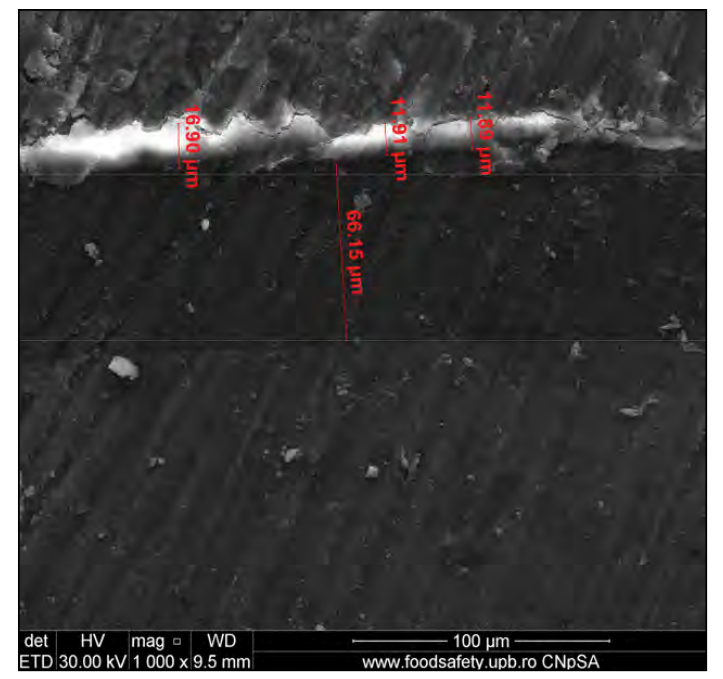

FIGURA 33. Zona de smalț-smalț hibridizat-primercompozit la mag. $1.000 x$, grosimea smalțului hibridizat $11,59-16,90 \mu m$

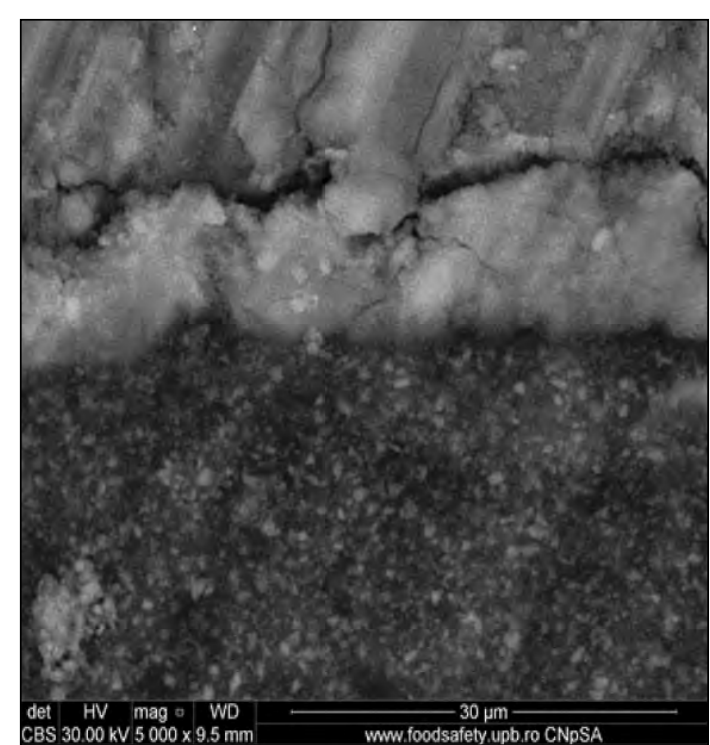

FIGURA 34. Aspect SEM al smalțului hibridizat, mag. $5.000 x$

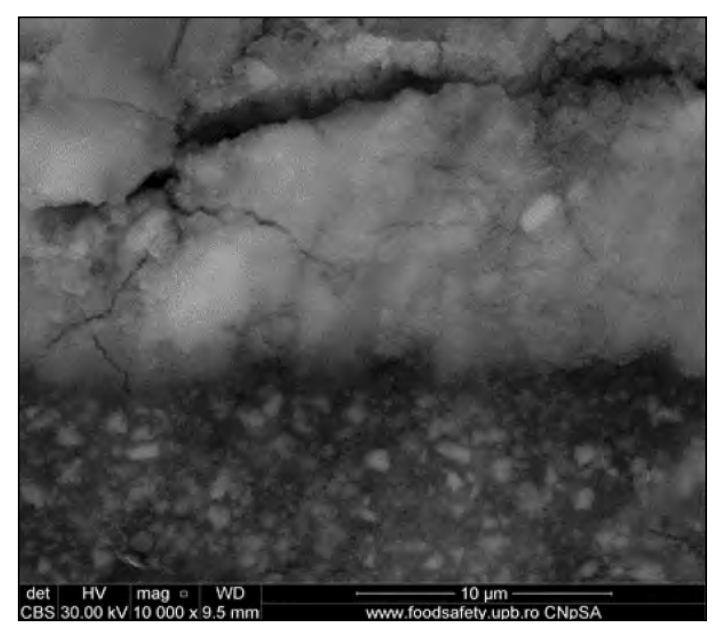

FIGURA 35. Aspect SEM al smalțului hibridizat, mag. $10.000 x$

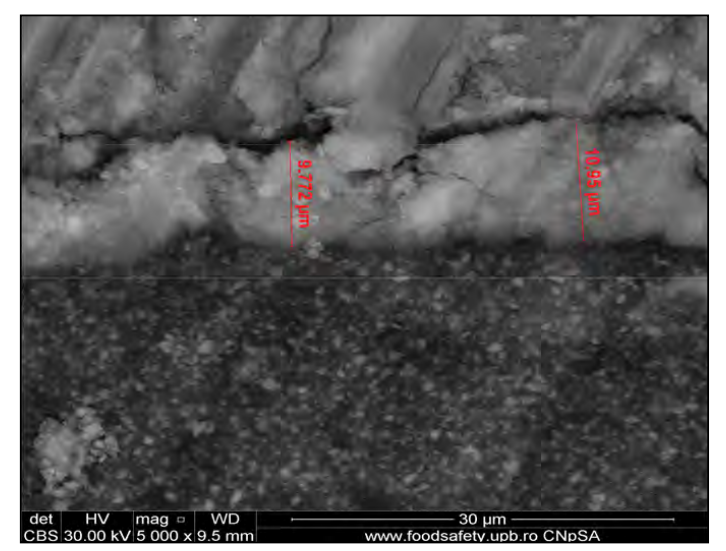

FIGURA 36. Zona de smalț-smalț hibridizat-primer la mag. $5.000 \times$, grosimea smalțului hibridizat 9,77-10,95 $\mu \mathrm{m}$ 


\section{Aspect SEM Grup 3}

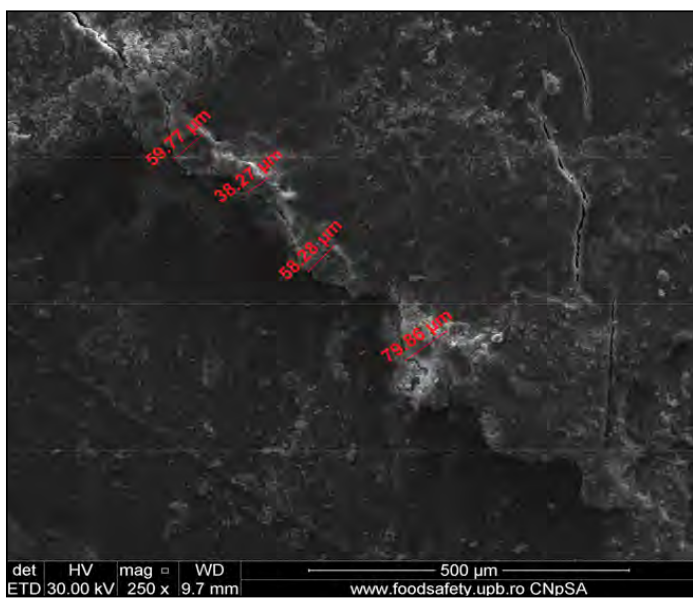

FIGURA 37. Aspect SEM al zonei smalț-smalț hibridizat-primer la mag. 250 x, grosimea smalțului hibridizat 38,27- 58,28-79,86 $\mu \mathrm{m}$

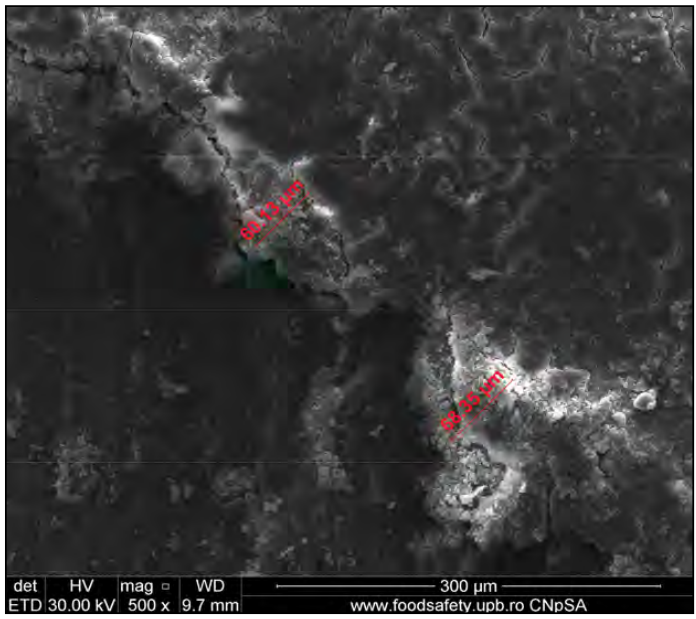

FIGURA 38. Aspect SEM al zonei smalț-smalț hibridizat-primer la mag. $500 x$, grosimea smalțului hibridizat 60,13-68,35 $\mu \mathrm{m}$

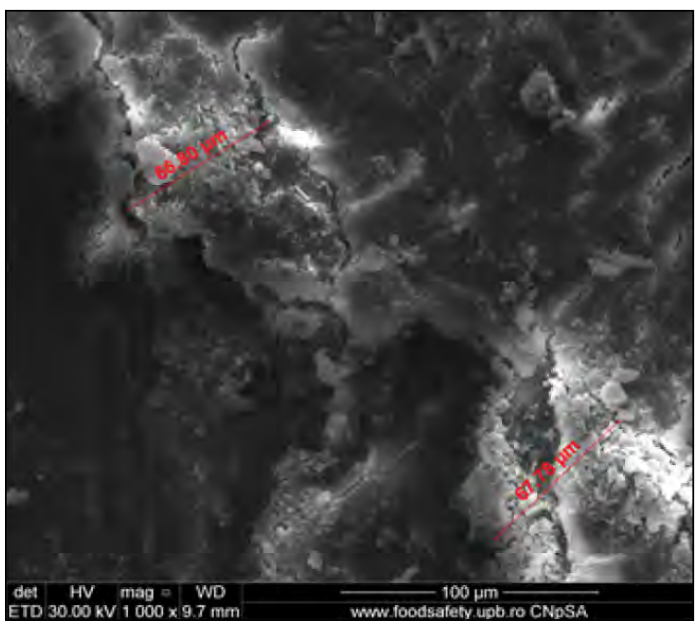

FIGURA 39. Aspect SEM al zonei smalț-smalț hibridizatprimer la mag. $1.000 \times$, grosimea smalțului hibridizat $66,80-67,70 \mu \mathrm{m}$

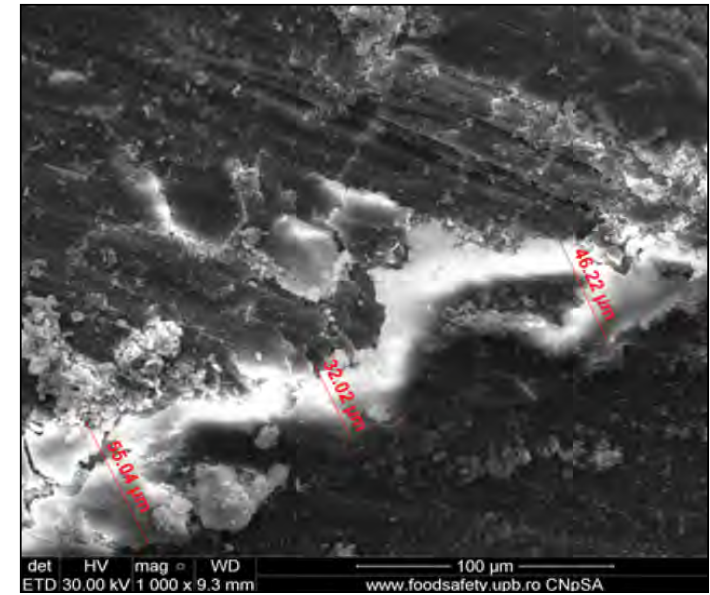

FIGURA 40. Aspect SEM al zonei smalț-smalț hibridizatprimer la mag. $1.000 \times$, grosimea smalțului hibridizat 32,02 $-46,22-55,04 \mu \mathrm{m}$

TABELUL 1. Grosimea stratului hibrid

\begin{tabular}{|c|c|c|}
\hline Grup & Timp de demineralizare & Grosime strat hibrid \\
\hline G1 & $30 \mathrm{sec}$. & $2,869-9,242 \mu \mathrm{m}$ \\
\hline G2 & $45 \mathrm{sec}$. & $4,175-16,90 \mu \mathrm{m}$ \\
\hline G3 & $60 \mathrm{sec}$. & $32,02-79,86 \mu \mathrm{m}$ \\
\hline
\end{tabular}

Mărirea peste $30 \mathrm{sec}$. a timpului de demineralizare cu acid fosforic a smalţului, valoare care dă un tipar favorabil de demineralizare pentru adeziune, are drept consecinţă formarea, în urma aplicării primerului, a unui strat hibrid cu grosime crescută.

\section{DISCUŢII}

O problemă des întâlnită în ortodonţie este reprezentată de apariţia posttratament ortodontic a unor pete alb cretoase pe fețele vestibulare ale dinţilor şi în jurul inelelor ortodontice. Acest aspect inestetic poate fi diminuat în mod fiziologic în timp prin remineralizarea suprafeţei, ca urmare a schimbului de de ioni minerali dintre salivă şi smalţ. Dar există şi cazuri în care aceste leziuni se permanentizează (1).

Demineralizarea progresivă a smalţului, fără o remineralizare adecvată, determină dezvoltarea leziunilor white spot.

Există două direcţii de demineralizare a smalţului, una provine din alimentaţie şi igiena incorectă, iar cea de-a doua poate fi legată de folosirea unei tehnici adezive incorecte.

Adezivii ortodontici universali includ 3 etape: demineralizare cu acid fosforic, aplicarea primerului şi apoi a răşinii adezive necesare pentru colarea bracketurilor la smalţ. Dar s-a constatat că folosirea 
acidului fosforic prezintă şi dezavantaje: pierdere crescută de smalţ, fisuri în smalţ, decalcifierea smalţului şi apariţia leziunilor white spot (2).

În ciuda eforturilor făcute pentru diversificarea tehnicilor adezive, se pare că demineralizarea smalţului rămâne cea mai efícientă şi stabilă tehnică de adeziune (3).

După demineralizare, cristale noi de apatită pot fi create prin remineralizare. Nivelul şi rezultatul acestor procese reparative depind de tipul agentului de demineralizare, concentraţia acidului, orientarea cristalelor în raport cu suprafaţa dintelui, dar cel mai mult depind de timpul de demineralizare (4).

Când se stabileşte timpul de demineralizare, trebuie să ţinem cont de tipul smalţului. Astfel, smalţul dinţilor temporari este predominant aprismatic, iniţial s-a propus un timp de demineralizare de 120 sec., care apoi a fost redus la $60 \mathrm{sec}$.

În cazul sigilanţilor pentru şanţuri şi fosete, a smalţului aprismatic al dinţilor permanenţi şi a bracketurilor ortodontice, timpul de demineralizare este de 20-30 sec.

În cazul smalţului prismatic, timpul de demineralizare a fost redus la $15 \mathrm{sec}$.

Dinţii cu o concentraţie mare de fluoruri sunt consideraţi mai rezistenţi la demineralizare acidă decât dinţii normali şi pot necesita un timp de demineralizare mai extins.

Prin demineralizare se obţine un anumit grad de porozitate a suprafeţei smalţului, cu adâncime de $10 \mu \mathrm{m}$, după îndepărtarea plăcii bacteriene şi a smalţului superficial (5).

Forma predominantă de retenţie micromecanică în smalţul neprelucrat se obţine prin crearea de microporozităţi de suprafaţă şi subsuprafaţă, care determină apariţia unei zone de smalţ hibridizat, cu grosime 8-10 $\mu \mathrm{m}$, alcătuit atât din smalţ prismatic, cât şi aprismatic (6).

Acidul fosforic demineralizează suprafaţa smalțului pană la o adâncime variabilă de 5-25 $\mu \mathrm{m}$ (7).

Angulaţiile diferite ale cristalelor prismelor determină o demineralizare acidă mai mare în anumite microregiuni. Acidul demineralizant îndepărtează aproximativ $10 \mu \mathrm{m}$ din suprafaţa smalţului şi creează un strat poros din punct de vedere morfologic, cu o grosime de $5-50 \mu \mathrm{m}(3,8,9)$

În acest studiu s-au analizat efectele asupra smalţului dentar ale demineralizării realizate în vederea aplicării adezive a bracketurilor ortodontice timp de 30 sec., 45 sec. si respectiv 60 sec. S-a observat că mărirea timpului de demineralizare la $60 \mathrm{sec}$. determină formarea unui strat hibrid gros $(32,02-79,86 \mu \mathrm{m})$.

În urma îndepărtării bracketurilor, aspectul întâlnit poate fi de pată alb cretoasă, dacă compozitul rămane pe talpa acestora. În caz contrar, la îndepărtarea compozitului cu ajutorul instrumentarului rotativ, este posibilă şi îndepărtarea statului superficial de smalţ hibridizat, cu aparitia fisurilor în smalţ şi pierdere consecutivă de substanţă dentară.

Modificările micromorfologice care apar în smalţ după demineralizare de $60 \mathrm{sec}$, respectiv 120 sec., cu acid fosforic gel $37 \%$, au fost studiate şi comparate şi de Sava Rosianu şi colab. (3), care arată că demineralizarea modifică aspectul morfologic al smalţului, indiferent de timpul de demineralizare. Suprafeţele de smalţ demineralizate cu acid fosforic $37 \%$ prezintă modele similare de demineralizare. Miezul prismei a fost îndepărtat preferenţial, lăsând periferia prismei relativ intactă.

$\mathrm{Nu}$ s-au observat diferenţe morfologice evidente în timpul de demineralizare a smalţului când acesta a fost tratat cu acid fosforic $37 \%$ pentru 60 respectiv $120 \mathrm{sec}$. Totuşi, demineralizarea de $60 \mathrm{sec}$. a produs o îndepărtare parţială a miezului prismei (3).

Alt studiu realizat de Martha şi colab. (7) evaluează tiparele de demineralizare şi morfologia după demineralizarea acidă în funcţie de durata de aplicare a acidului fosforic, care a fost 15, 30 şi $45 \mathrm{sec}$.

Când demineralizarea cu acid fosforic $37 \%$ s-a făcut pentru 15 sec. s-a observat o demineralizare moderată cu aspect buretos, care afectează mai mult spaţiile interprismatice. Se mai observă şi zone intacte, cel mai mult pe marginile suprafeţelor de smalţ demineralizate.

Când demineralizarea cu acid fosforic $37 \%$ s-a făcut pentru $30 \mathrm{sec}$., adâncimea şi morfologia zonelor demineralizate a crescut. Demineralizarea a fost mai mare la capul prismei şi la periferie. În zonele cu prisme orientate perpendicular pe suprafaţă, se observă şi demineralizarea zonelor interprismatice.

Când demineralizarea cu acid fosforic $37 \%$ s-a facut pentru 45 sec., se observă rugozitatea întregului smalţ. Sunt afectate ambele zone, atât smalţul interprismatic, cât şi cel intraprismatic, iar capetele prismelor sunt complet şterse. Apare aspectul de fagure de miere pe imaginea SEM (7). 
Studiul arată că zonele interprismatice sunt afectate atât la demineralizarea de $15 \mathrm{sec}$., cât şi la cea de $30 \mathrm{sec}$. Demineralizarea miezului prismei apare numai când atacul acid are o durată mai mare. Aceste modificări pot fi benefice pentru adeziunea bracketurilor, dar, după îndepărtarea acestora, remineralizarea ar putea fỉ insuficientă (7).

\section{CONCLUZII}

Plecând de la aceste constatări, putem spune că o demineralizare de $60 \mathrm{sec}$. a smalţului este urmată de formarea unui strat hibrid cu grosime mare şi cu o putere de adeziune mai mică, deoarece microre-

\section{BIBLIOGRAFIE}

1. Jumanca D, Galuscan A, Podariu AC, Ardelean L, RusuLC. Infiltration Therapy - an Alternative to Fluoride Varnish Application for Treatment of White Spot Lesion After Fixed Orthodontic Treatment. REV. CHIM. (Bucharest) 63(8),2012

2. Erdur EA, Yldirim M, Akin M. Comparasion of bond strenghts of self-etch adhesive systems in orthodontic bracketbonding procedure. Selcuk Dent J, 2017;4:128-133

3. Sava Rosianu R şi colab. Microscopic Assessment of the Enamel Etching Pattern According to Different Etching Times Using Orthophosphoric Acid Gels. Rev. Materiale plastice, 53(1),2016

4. Mártha $\mathrm{K}$ şi colab. Comparative SEM Analysis of the Effect of Acidic Monomers and Phosphoric Acids on Dental Enamel. Rev. Chim. (Bucharest),64 (8), 2013.

5. Jumanca $D$ şi colab. Comparative Study on the Adhesive Capacity of Four Adhesives Habitually used in Fixed Orthodontics. Rev. Materiale plastic. 48(4),2011. tenţiile obţinute printr-un timp mai redus de demineralizare sunt înlocuite de un tipar nefavorabil de demineralizare, de o, ,distrugere haotică““ a suprafeţei smalţului.

De asemenea, deşi după îndepărtarea bracketurilor suprafeţele de smalţ demineralizate se pot remineraliza cu ioni din salivă, cu cât demineralizarea a fost mai agresivă, cu atât şi remineralizarea va fi incompletă, favorizând instalarea leziunilor white spot.

\section{Mențiune}

Toţi autorii au contribuţie egală în realizarea acestui articol.
6. Eliades G, Watts DC, Eliades T. Dental Hard Tissues and Bonding: Interfacial Phenomena and Related Properties, cap. 1, pg. 3-33, Ed Springer, 2005.

7. Mártha $\mathrm{K}$ şi colab. The Effect of Phosphoric Acid Etching Application Time on the Enamel Morphology - a comparative SEM Study. REV. CHIM. (Bucharest). 64 (9)2013.

8. Van Meerbeek B et al. Enamel dentin adhesion. In: Schwartz RS, Summitt JB, Robbins JW, Fundamentals of Operative Dentistry. A Contemporary Approach Chicago, III: Quintessence; 1996 141-186.

9. Lampa E et al. Effect of a nonrinse conditioner on the durability of a polyacid-modified resin composite fissure sealant. J Dent Child. 2004 71:152-157. 